\title{
One-pot synthesis of hierarchically structured ZSM-5 zeolites using single micropore-template
}

\author{
Tongguang Ge, Zile Hua*, Xiaoyun He, Yan Zhu, Wenchao Ren, Lisong Chen, Lingxia Zhang, \\ Hangrong Chen, Chucheng Lin, Heliang Yao, Jianlin Shi\# \\ State Key Laboratory of High Performance Ceramics and Superfine Microstructure, Shanghai Institute of Ceramics, Chinese Academy of Sciences, \\ Shanghai 200050, China
}

\section{A R T I C L E I N F O}

\section{Article history:}

Received 30 October 2014

Accepted 10 December 2014

Published 20 June 2015

\section{Keywords:}

Hierarchically structured zeolite

ZSM-5

Single template

Base etching

Catalysis

\begin{abstract}
A B S T R A C T
An easy one-step hydrothermal process has been developed for the first time for the synthesis of hierarchically structured zeolites (HSZs) using a single micropore template of tetrapropylammonium hydroxide. Compared with conventional constructive dual-templating synthesis and destructive post-demetallation methods, this two-in-one process reduces the mass of porogens required and consequent air pollution by combustion of the template, and simplifies the synthesis. The resultant HSZs were characterized by X-ray diffraction, $\mathrm{N}_{2}$ adsorption, scanning electron microscopy, transmission electron microscopy, X-ray fluorescence, ${ }^{27} \mathrm{Al}$ nuclear magnetic resonance, and $\mathrm{NH}_{3}$ temperature programmed desorption. The resultant HSZs with uniform shuttle-type morphology showed high hydrothermal stability and excellent catalytic activity with prolonged life-time in the model reaction of 1,3,5-triisopropylbenzene cracking. A "nucleation/growth-demetallation/recrystallization" mechanism was proposed, which is featured with the integration of zeolite crystallization/growth and basic etching into one hydrothermal process for HSZs production.
\end{abstract}

(C) 2015, Dalian Institute of Chemical Physics, Chinese Academy of Sciences. Published by Elsevier B.V. All rights reserved.

\section{Introduction}

Zeolites are an important catalyst type and support and have been used extensively in the petrochemical and fine chemical industries, because of their peculiar and uniform microporous structure, large specific surface area, intrinsic acidity, and high hydrothermal/thermal stability [1,2]. However, they exhibit restricted reactant/product transport to/from the active sites in microporous channels, and their application in catalytic reactions involving bulky molecules is therefore lim- ited $[3,4]$. Limited mass transport is encountered frequently, even for relatively small molecule reactants that could enter micropores. This slows down reactions, increases the possibility of secondary reactions and coke formation, and leads to the degradation of material catalytic performance [5,6]. To alleviate diffusion limitations in microporous channels, nanosized zeolite crystals with a short diffusion path have been investigated, but the low yield and separation difficulty of nanozeolites limit their practical application [7,8]. Hierarchically structured zeolites (HSZs), which combine crystalline microporous

\footnotetext{
* Corresponding author. Tel: +86-21-52412708; Fax: +86-21-52413122; E-mail: huazl@mail.sic.ac.cn

\# Corresponding author. Tel: +86-21-52412712; Fax: +86-21-52413122; E-mail: jlshi@mail.sic.ac.cn

This work was supported by the National Basic Research Program of China (2013CB933200), the National High Technology Research and Development Program of China (2012AA062703), China National Funds for Distinguished Young Scientists (51225202), and the Opening Projects of State Key Laboratory of Heavy Oil Processing (SKLOP201402003).

DOI: 10.1016/S1872-2067(14)60263-1 | http://www.sciencedirect.com/science/journal/18722067 | Chin. J. Catal., Vol. 36, No. 6, June 2015
} 
frameworks and auxiliary mesoporous structures, have attracted attention recently [9-14]. These materials show superior performance in a wide range of reactions, such as catalytic cracking [15], alkylation of aromatic compounds [16,17], methanol to hydrocarbons [5], and oxidation of organic compounds [18].

Over the past decade, a variety of synthetic approaches have been developed for the preparation of HSZs. These can be classified roughly as bottom-up "constructive" and top-down "deconstructive" categories. In the constructive method, since a large amount of organic or inorganic templates are used, thermal treatment or acid washing is inevitable to unclose the porous structures [19-21]. During this template-directed HSZs synthesis, and to avoid the occurrence of phase separation between microporous crystals and amorphous mesoporous species, carefully selected or specially designed dual pore-making templates, i.e., porogens, are usually necessary [11,22]. For example, the combinations of the micropore template of tetrapropylammonium hydroxide (TPAOH) with various mesoporogens such as P123, F127, TEA, CTAB, and other specially synthesized organosilanes have been reported [9,23-26]. However, the low-cost synthesis of HSZs using a single template is still a challenge. Alternatively, the "deconstructive" method is a multi-step process, which often involves the synthesis of microporous crystals and then acid treatment for dealumination or base treatment for desilication, or a combination of these processes to generate additional mesoporous structures [27-29]. For this post-synthetic process, although there are some reports about scaled-up synthesis of HSZs, there is a $\mathrm{Si} / \mathrm{Al}$ molar ratio limitation, such as $\sim 25-50$ for ZSM-5 zeolites $[30,31]$. Otherwise, special processing strategies would be required [32]. To reduce the usage of porous templates and/or simplify synthesis, a new methodology is desired for the HSZs preparation.

We report on an easy one-pot hydrothermal procedure for the synthesis of hierarchically structured ZSM-5 zeolites using a single micropore template of TPAOH. Synthesized ZSM-5 HSZs have well-crystallized microporous frameworks and extensive mesoporous structure at a low hydrothermal temperature of $100{ }^{\circ} \mathrm{C}$, and consequently show excellent hydrothermal stability and superior performance in the model reaction of 1,3,5-triisopropylbenzene (TIPB) catalytic cracking. Based on the characterization of synthesized HSZs with various hydrothermal crystallization periods, it is proposed that their structural development undergo a "nucleation/growth-demetallation/recrystallization" mechanism.

\section{Experimental}

\subsection{Preparation of hierarchically structured ZSM-5 zeolite}

Typically, the preparation of HSZs was based on the following procedure. Tetraethyl orthosilicate $(15.624 \mathrm{~g}$ ) and $0.3066 \mathrm{~g}$ aluminium isopropoxide (Adamas Reagent Co., Ltd., China) were mixed at room temperature for $0.5 \mathrm{~h}$ under continuous stirring. Deionized water ( $45.0 \mathrm{~g}$ ) was added into the mixture and stirred for a further $0.5 \mathrm{~h}$. TPAOH solution (10.98 g, 25\%) was added dropwise into the above mixture with rigorous stirring for $3 \mathrm{~h}$ at $40^{\circ} \mathrm{C}$, followed by the dropwise addition of sodium hydroxide $(\mathrm{NaOH}, 0.27 \mathrm{~g}$ in $90.0 \mathrm{~g}$ water). The typical composition molar ratio was $75 \mathrm{SiO}_{2} / 0.75 \mathrm{Al}_{2} \mathrm{O}_{3} / 10 \mathrm{NaOH} /$ $7500 \mathrm{H}_{2} \mathrm{O} / 12.4 \mathrm{TPAOH}$. The resultant mixture was stirred for another $4 \mathrm{~h}$ before hydrothermal treatment at $100{ }^{\circ} \mathrm{C}$ under continuous stirring. The obtained samples were defined as HSZs- $t$, in which $t$ represents the hydrothermal crystallization time (h).

\subsection{Characterization}

Power X-ray diffraction (XRD) was performed to investigate the crystallinity of prepared samples on a Rigaku D/Max $2200 \mathrm{PC}$ diffractometer with $\mathrm{Cu} K_{\alpha}$ radiation $(40 \mathrm{kV}, 40 \mathrm{~mA})$ at a scanning rate of $6 \% \mathrm{~min}$. $\mathrm{N}_{2}$ adsorption and desorption isotherms were obtained using an ASAP 2020 at $-196{ }^{\circ} \mathrm{C}$. The sample specific surface area was calculated by the Brunauer-Emmett-Teller (BET) method and the pore size distribution by the Barrett-Joyner-Halenda (BJH) method using the desorption branch. The external surface area and micropore volume were measured by the $t$-plot method. Field emission scanning electron microscopy (FE-SEM) images were recorded on a FEI-Magellan 400L operated at $1 \mathrm{kV}$ and transmission electron microscopy (TEM) images were recorded on a JEOL-2010F at $200 \mathrm{kV}$. High-angle annular dark-field scanning transmission electron microscopy (HAADF-STEM) images were obtained on a FEI-TECNAI F20. The temperature-programmed desorption of ammonia ( $\mathrm{NH}_{3}$-TPD) was carried out on a Micromeritics Chemisorb 2750. Solid state ${ }^{27} \mathrm{Al}$ spectra were obtained on a Bruker Avance III spectrometer.

\subsection{Catalytic reaction}

The cracking of TIPB was conducted to evaluate the catalytic activity of the prepared catalysts. In a typical experiment, the reaction was carried out in a continuous flow fixed-bed reactor under atmospheric pressure using $\mathrm{N}_{2}$ as the carrier gas at 30 $\mathrm{ml} / \mathrm{min}$ and $500{ }^{\circ} \mathrm{C}$ for $10 \mathrm{~h}$. Before the reaction, the catalysts were activated at $500{ }^{\circ} \mathrm{C}$ for $1.5 \mathrm{~h}$ in $\mathrm{N}_{2}(30 \mathrm{ml} / \mathrm{min})$. The reactant was injected into the reaction system at $0.02 \mathrm{ml} / \mathrm{min}$ (space velocity $6.0 \mathrm{ml} /(\mathrm{g} \cdot \mathrm{h})$ ) using a plunger pump and vaporized at $300{ }^{\circ} \mathrm{C}$ before catalytic reaction. The resultant products were condensed by reflux condensation alcohol at $0{ }^{\circ} \mathrm{C}$. The products were separated and analysed on a gas chromatograph (Shimadzu GC-2010 plus). The conversion and selectivity over the HSZs and a conventional ZSM-5 zeolite were compared to evaluate the activity and anti-deactivation properties of the corresponding catalysts.

\section{Results and discussion}

A series of HSZs- $t$ samples were synthesized with varied hydrothermal crystallization periods and corresponding product yields of $34.0 \%-93.5 \%$. Fig. 1 shows the powder XRD results for HSZs- $t$ and conventional ZSM-5. All show characteristic patterns of MFI-type zeolites, which indicates the successful 


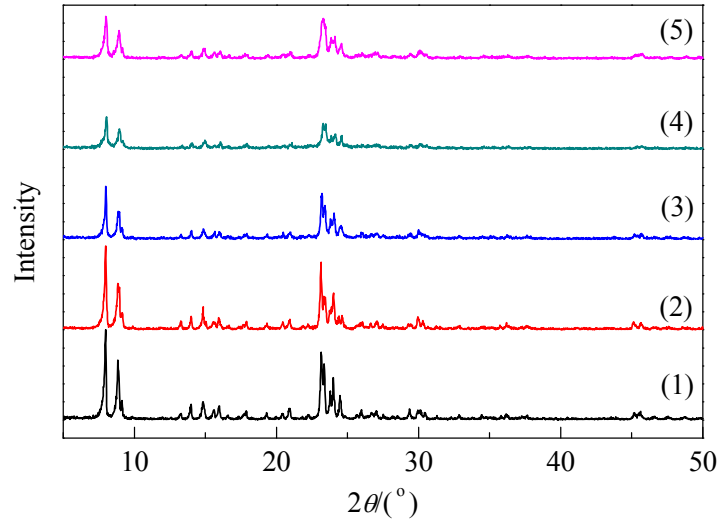

Fig. 1. Wide angle X-ray diffraction patterns of conventional ZSM-5 (1) and calcined HSZs-24 (2), HSZs-40 (3), HSZs-120 (4), and HSZs-240 (5).

formation of well-crystallized ZSM-5 particles [11]. However, depending on the hydrothermal time duration in HSZs synthesis, a gradual decrease in relative crystallinity occurs. Since similar phenomena are often observed in the post-demetallation synthesis of HSZs, an in-situ base etching process has probably occurred during this one-pot low-temperature hydrothermal procedure [15,27].

To clarify the pore structure development of HSZs-t, $\mathrm{N}_{2}$ adsorption-desorption isotherm characterization was conducted for HSZs and ZSM-5. As shown in Fig. 2(a), ZSM-5 exhibits a representative type I isotherm, which reflects its microporous structure. HSZs- $t$ (especially HSZs-120), show type II isotherms
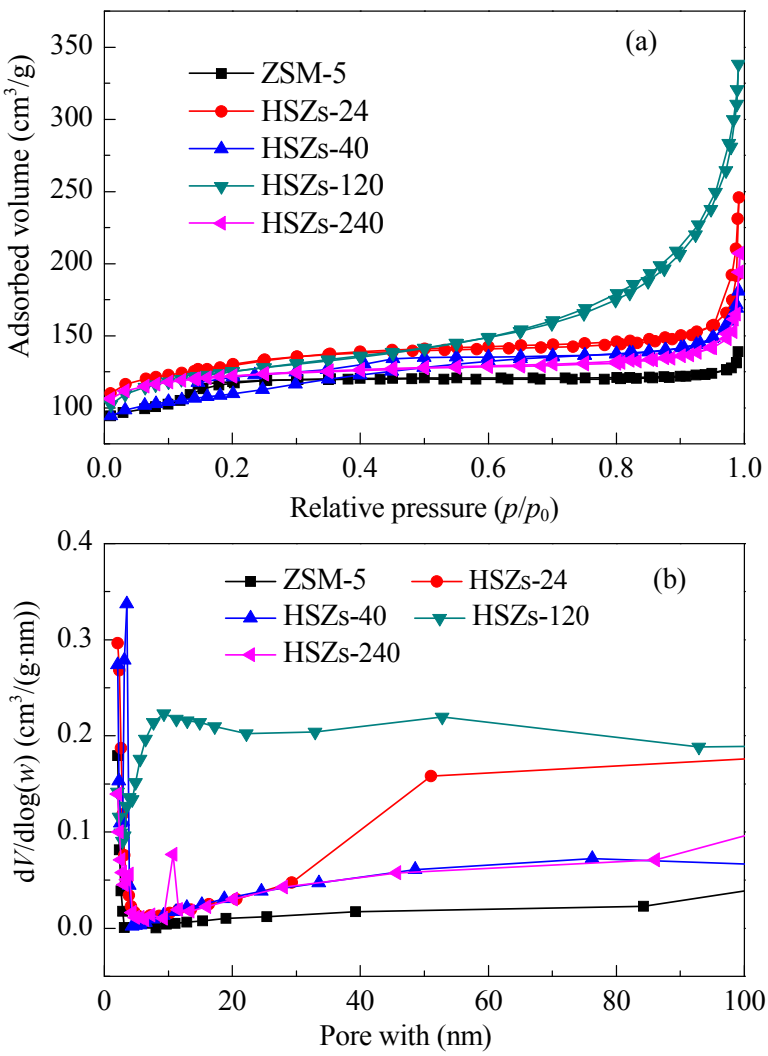

Fig. 2. $\mathrm{N}_{2}$ adsorption-desorption isotherms (a) and pore size distributions (b) of conventional ZSM-5 and calcined HSZs- $t$ materials. with a H3-type hysteresis loop and a steep increase for $0.7<$ $p / p_{0}<0.95$, which suggests the presence of large mesopores. Fig. 2(b) shows pore size distributions of the synthesized materials. For sample HSZs-120, a broad peak over $10-80 \mathrm{~nm}$ is present. In comparison, conventional ZSM-5 shows no distinct mesopore distribution because of the absence of sharp uptake at high $p / p_{0}$. Table 1 summarizes the textural properties of the synthesized HSZs- $t$ and ZSM-5. The BET surface area, total pore volume, and mesopore volume of HSZs- 120 are $427 \mathrm{~m}^{2} / \mathrm{g}, 0.41$ $\mathrm{cm}^{3} / \mathrm{g}$, and $0.29 \mathrm{~cm}^{3} / \mathrm{g}$, respectively, which are larger than those of the conventional ZSM-5 $\left(397 \mathrm{~m}^{2} / \mathrm{g}, 0.19 \mathrm{~cm}^{3} / \mathrm{g}\right.$, and $0.05 \mathrm{~cm}^{3} / \mathrm{g}$, respectively). However, both showed similar micropore volumes $\left(0.12 \mathrm{~cm}^{3} / \mathrm{g}\right.$ versus $0.14 \mathrm{~cm}^{3} / \mathrm{g}$, respectively). Combined with the XRD results, a preliminary conclusion is obtained that HSZs with well-crystallized frameworks (HSZs-120) have been synthesized successfully. HSZs-120 also exhibits excellent hydrothermal stability (Fig. 3). After hydrothermal treatment at $150{ }^{\circ} \mathrm{C}$ for $48 \mathrm{~h}, 88 \%$ of the specific surface area $\left(385 \mathrm{~m}^{2} / \mathrm{g}\right.$ versus $\left.436 \mathrm{~m}^{2} / \mathrm{g}\right)$ is maintained and the total pore volume is almost unchanged $\left(0.36 \mathrm{~cm}^{3} / \mathrm{g}\right.$ versus 0.35 $\mathrm{cm}^{3} / \mathrm{g}$ ).

\section{Table 1}

Structure parameters of calcined HSZs- $t$ and conventional ZSM-5.

\begin{tabular}{lccccc}
\hline Sample & $\begin{array}{c}S_{\text {BET }} \\
\left(\mathrm{m}^{2} / \mathrm{g}\right)\end{array}$ & $\begin{array}{c}S_{\text {micro }} \\
\left(\mathrm{m}^{2} / \mathrm{g}\right)\end{array}$ & $\begin{array}{c}S_{\text {ext }} \\
\left(\mathrm{m}^{2} / \mathrm{g}\right)\end{array}$ & $\begin{array}{c}V_{\text {pore }} \\
\left(\mathrm{cm}^{3} / \mathrm{g}\right)\end{array}$ & $\begin{array}{c}V_{\text {micro }} \\
\left(\mathrm{cm}^{3} / \mathrm{g}\right)\end{array}$ \\
\hline HSZs-24 & 372 & 244 & 128 & 0.24 & 0.11 \\
HSZs-40 & 417 & 252 & 165 & 0.31 & 0.12 \\
HSZs-120 & 427 & 269 & 158 & 0.41 & 0.12 \\
HSZs-240 & 412 & 317 & 96 & 0.23 & 0.15 \\
ZSM-5 & 397 & 280 & 117 & 0.19 & 0.14 \\
\hline
\end{tabular}
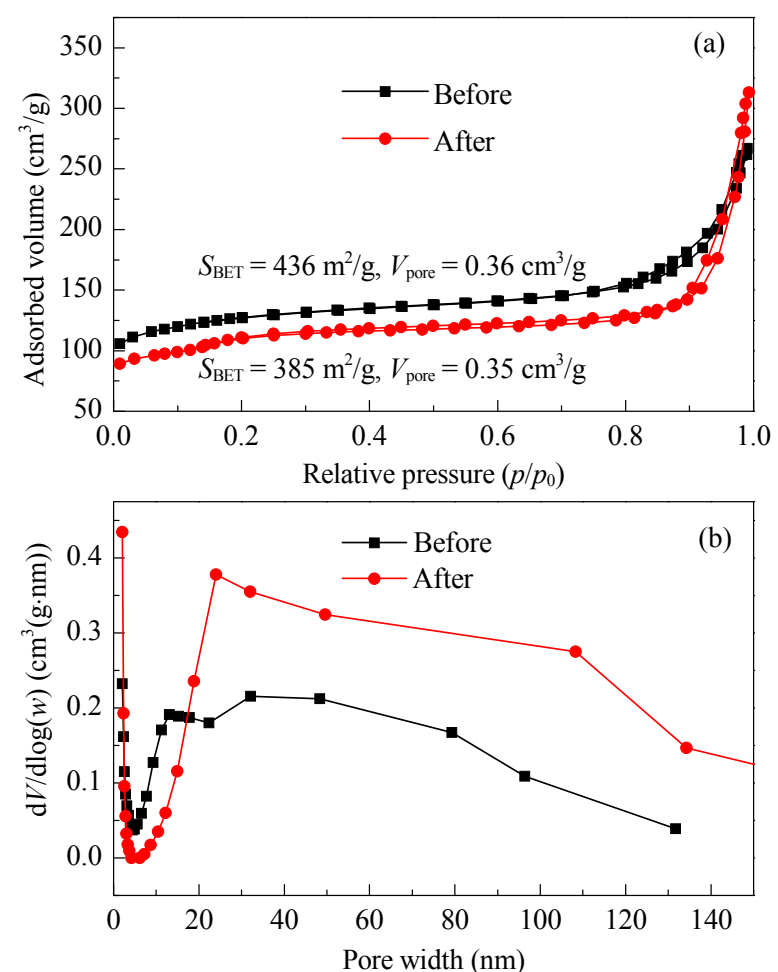

Fig. 3. $\mathrm{N}_{2}$ sorption isotherms (a) and corresponding pore size distribution (b) of HSZs-120 before and after hydrothermal treatment at $150^{\circ} \mathrm{C}$ for $48 \mathrm{~h}$. 


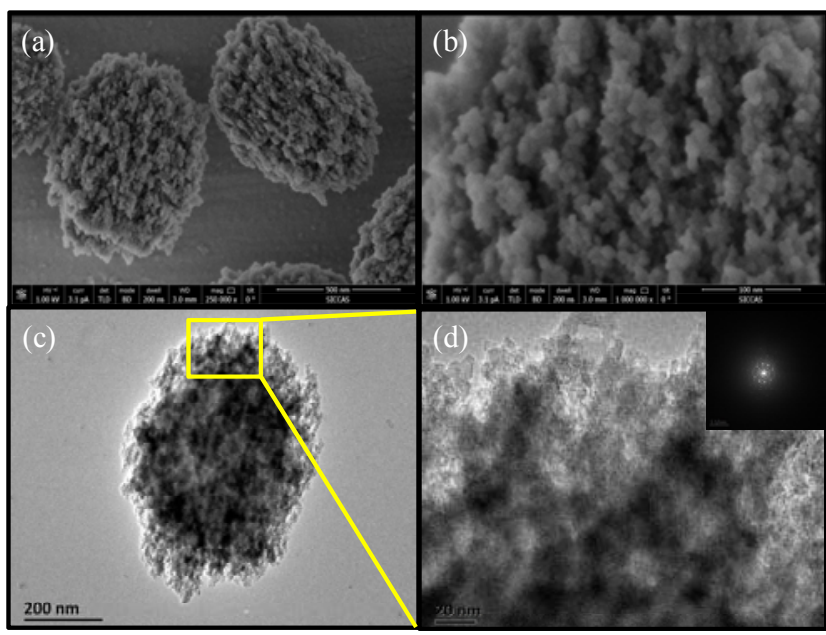

Fig. 4. FE-SEM images (a, b) of calcined HSZs-120 at different magnifications; TEM image (c) of a representative HSZs-120 particle; high-resolution TEM image (d) squared in (c) and the inset is the corresponding SAED pattern.

FE-SEM image (Fig. 4(a)) of HSZs-120 indicates that the sample consists of uniform shuttle-like 800-1000 $\mathrm{nm}$ particles with a rough surface. At higher magnification (Fig. 4(b)), mesopores over $10-80 \mathrm{~nm}$ are visible, which is consistent with the $\mathrm{N}_{2}$ adsorption-desorption results, and indicates abundant mesoporosity. Because of the density difference of the crystallized frameworks and the mesopore areas, in the TEM image of Fig. 4(c), the clear bright-to-dark contrast reflects the development of mesoporosity in the synthesized hierarchical zeolite crystals. The high-resolution TEM image and corresponding selected area electron diffraction (SAED) in Fig. 4(d) reveal parallel lattice fringes throughout the entire particle and periodic diffraction spots, which demonstrates the single crystalline nature of HSZs-120, and that the introduction of mesopores maintains the single crystal integrity. The creation of extensive mesoporosity could be more distinctly identified from HAADF-STEM (Fig. 5) projection, which demonstrates an even clearer contrast of mesopores on the selected smaller particle. The corresponding fast Fourier transformation also provides evidence as to its single crystal property.

The aluminum content of HSZs-120 was determined by $\mathrm{X}$-ray fluorescence (XRF). The $\mathrm{Si} / \mathrm{Al}$ ratio is $\sim 46.6$ and is close to 50 in the initial gel composition. The ${ }^{27} \mathrm{Al}$ magic-angle spin-

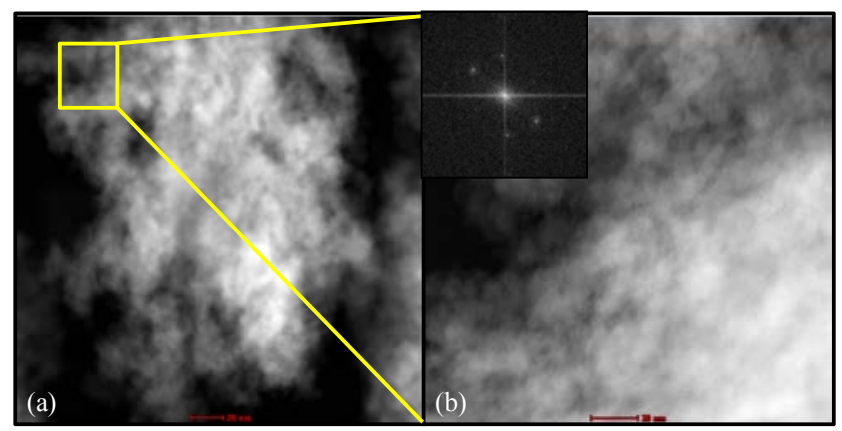

Fig. 5. HAADF-STEM image of selected small calcined HSZs-120 particle (a) and high-resolution HAADF-STEM image (b) squared in (a), the inset image in (b) is the corresponding fast Fourier transformation diffractogram.

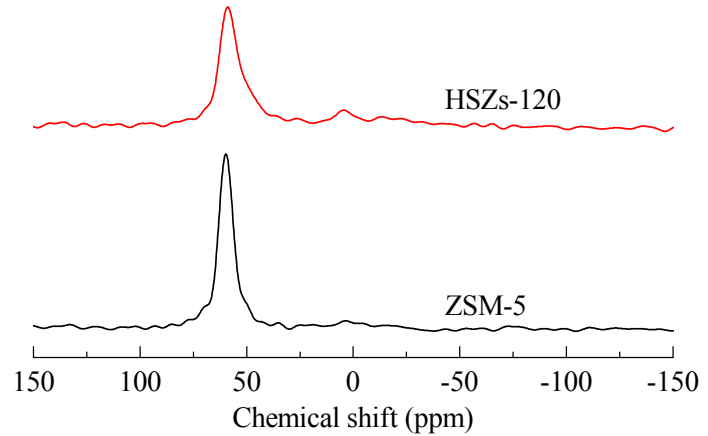

Fig. 6. Solid-state ${ }^{27} \mathrm{Al}$ MAS NMR spectra of conventional ZSM-5 and calcined HSZs-120.

ning nuclear magnetic resonance (MAS NMR) spectrum was investigated to characterize the $\mathrm{Al}$ coordination state in the synthesized HSZs-120. Fig. 6 confirms that the Al species are coordinated tetrahedrally into the zeolitic framework based on the strong signal at $60 \mathrm{ppm}$, whereas the negligible signal at 0 ppm suggests the absence of an octahedral extra-framework $\mathrm{Al}$ species [15]. $\mathrm{NH}_{3}$-TPD (Fig. 7) was conducted to compare the acidity of HSZs-120 with that of conventional ZSM-5. Both show similar profiles with desorption peaks at 140 and $330{ }^{\circ} \mathrm{C}$ that represent weak and strong acidity, respectively, which proves that the integration of mesopores into the crystalline framework has a negligible influence on material acidity.

To verify the beneficial effect of the introduction of mesoporosity into microporous ZSM-5 on the bulky molecules involved in the reactions, the cracking of TIPB was adopted as a model reaction for synthesized HSZs-120 and conventional ZSM-5. The TIPB conversion and product distributions over ZSM-5, HSZs-120, and HSZs-240 are plotted as a function of reaction time in Fig. 8. As expected, since the molecular size of TIPB is $\sim 0.95 \mathrm{~nm}$, which is much larger than the micropore size of ZSM-5 (0.55 nm), the conventional ZSM-5 showed a rather low conversion of $\sim 50 \%$ in the initial stage, followed by rapid deactivation of the catalyst. In $\sim 7 \mathrm{~h}$, the TIPB conversion decreased by $80 \%$ and then experienced less than $\sim 10 \%$ conversion over the following $3 \mathrm{~h}$. When synthesized HSZs-120 was used, it exhibited a much higher initial TIPB conversion of $\sim 80 \%$, which demonstrates that the introduction of mesopo-

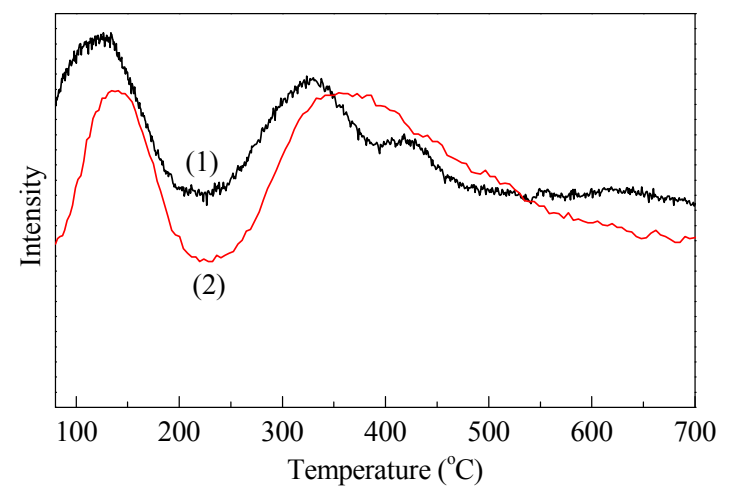

Fig. 7. $\mathrm{NH}_{3}-\mathrm{TPD}$ profiles of conventional ZSM-5 (1) and calcined HSZs-120 (2). 

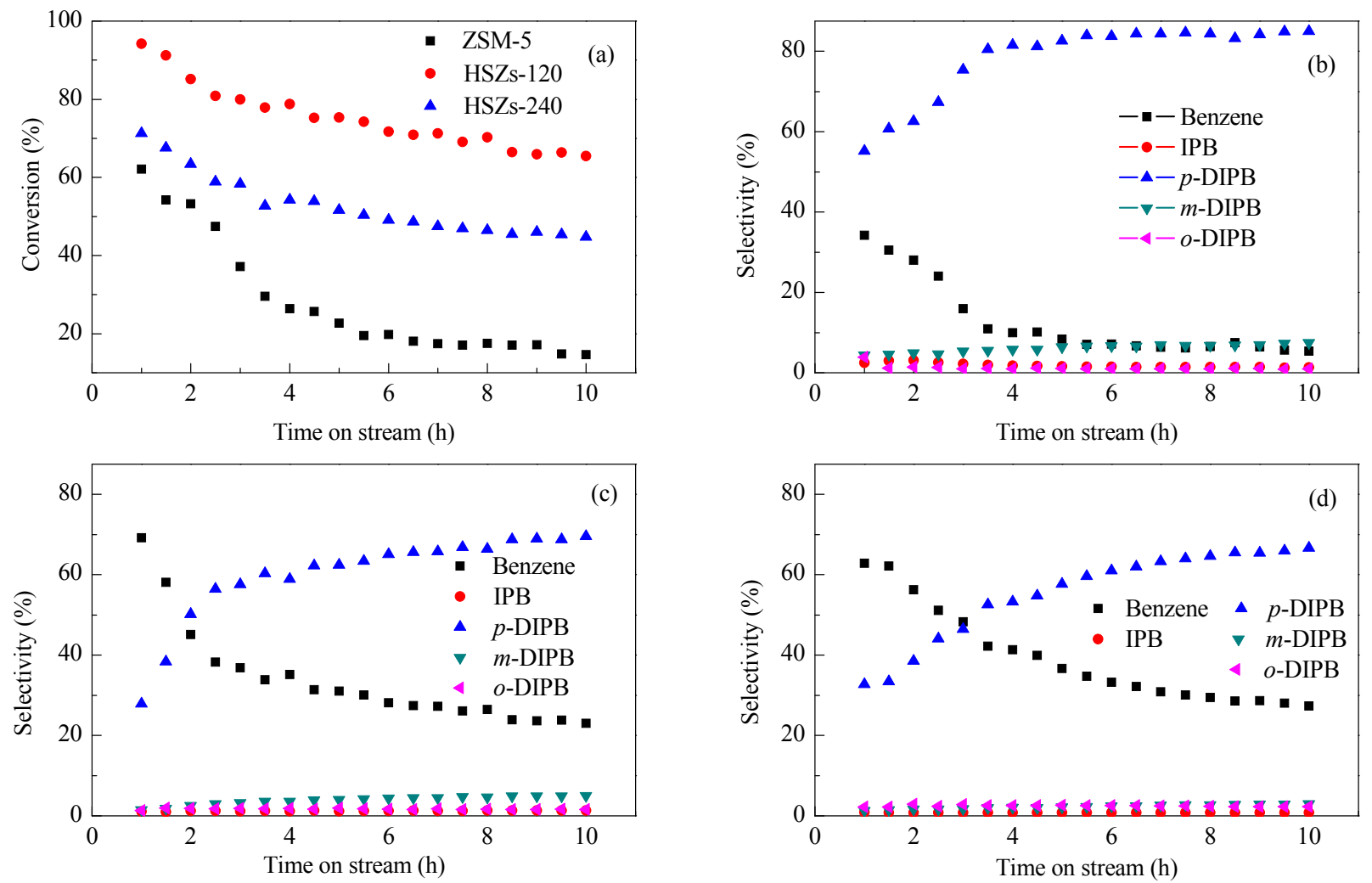

Fig. 8. TIPB conversion (a) and product selectivity over conventional ZSM-5 (b), HSZs-120 (c), and HSZs-240 (d) as a function of time on stream.

rosity benefits the catalytic performance of HSZs. The catalyst deactivation was slow; in the $10 \mathrm{~h}$ continuous cracking test, the TIPB conversion decreased by $20 \%$ and the last conversion of $65 \%$ was even higher than the initial TIPB conversion over the conventional ZSM-5. Both the increased external surface area and the shortened diffusion path in the microporous channels, which resulted from the introduction of mesoporosity in microporous ZSM-5, contribute to the enhancement of initial conversion and the substantial suppression of HSZs-120 deactivation. Although a lower catalytic activity resulted for sample HSZs-240 because of its deteriorated mesoporosity compared with that of HSZs-120, it is still superior to that of microporous ZSM-5. This is shown in Fig. 8(a), which indicates the important role of mesoporosity on the bulky TIPB cracking reaction.

To obtain more information through this cracking reaction, the product distributions over HSZs-120 and conventional ZSM-5 (Fig. 8(b) and (c)) were analyzed in detail. In the cracking reaction of TIPB, possible products include propene (gas), diisopropylbenzene (DIPB), isopropylbenzene (IPB), and benzene. Their relative contents depend on the cracking degree of TIPB with the sequential depletion of isopropyl groups from the benzene ring. For ZSM-5-type catalysts, because of the shape-selectivity property of uniform micropores, $p$-DIPB is the major component among three kinds of isomers of $p-, m-$, and $o$-DIPB. When the microporous ZSM-5 catalyst was used, because of the large molecular size of TIPB and pore blocking by cokes, the reactants are restricted significantly in accessing active sites in the microporous channels. Thus, $p$-DIPB was always the major component. At the end of the $10 \mathrm{~h}$ time-on-stream test, the $p$-DIPB selectivity was larger than $85 \%$ and the portion of the deeply cracking product of benzene was lower than $5 \%$. However, when HSZs-120 was used, at the beginning of the reaction, benzene was the major product and its selectivity was as high as $\sim 60 \%$. Simultaneously, the selectivity to $p$-DIPB was much lower at $35 \%$. By extending the time-on-stream, the benzene content decreased gradually and the $p$-DIPB selectivity increased accordingly, whereas the other product content remained almost unchanged. This indicates that part of the active sites deactivated. A similar product distribution was also observed over HSZs-240 (Fig. 8(d)). These results demonstrate that the introduction of mesoporosity in microporous ZSM-5 crystals not only increases catalyst reactivity, but also deepens the cracking reaction. The HSZs-120 and conventional ZSM-5 catalysts were analyzed by thermogravimetry. As shown in Fig. 9, from 300 to $800{ }^{\circ} \mathrm{C}$, the mass loss of ZSM-5 catalyst is $\sim 2.1 \%$, whereas that of HSZs-120 is $\sim 3.5 \%$. Compared with conventional microporous zeolites, HSZs-120 therefore possesses a higher coke-tolerant capability. As mentioned previously, since the molecular size of TIPB is larger than the micropore size of ZSM-5, most reactions could only occur on the limited external surface or near the micropore mouth of the ZSM-5 crystals [3,4]. Thus, even relatively little coke formation would lead to rapid catalyst deactivation. However, for hierarchically structured ZSM-5 zeolites, the auxiliary mesoporous structures not only increase the external surface area and consequently the amount of more accessible active sites for bulky TIPB molecules, but also help to shorten the molecular diffusion path and the residence time of reac- 


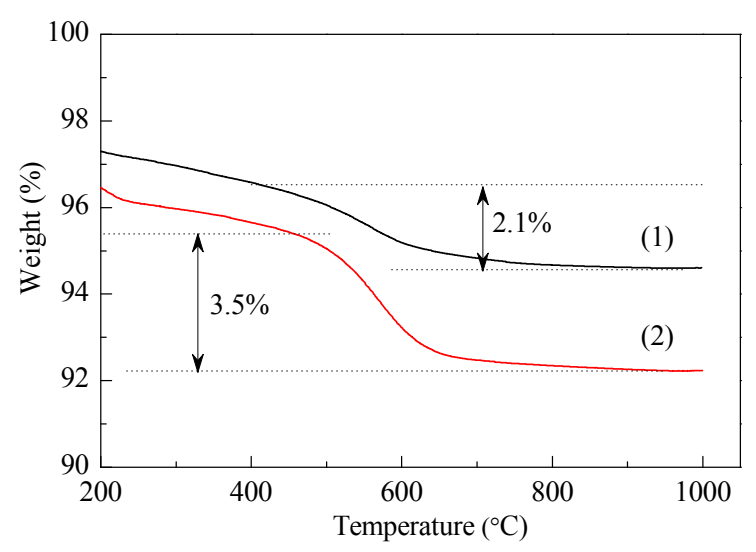

Fig. 9. TG profiles of conventional ZSM-5 (1) and HSZs-120 (2) in the TIPB cracking test at $500^{\circ} \mathrm{C}$ for $10 \mathrm{~h}$.

tants, intermediates, and products in the micropore channels. As a result, the possibility of coke formation near the micropore mouth, and the detrimental effect of coke formation in the mesoporous structures on catalyst performance are decreased significantly.

The samples crystallized at different intervals were characterized to understand HSZs evolution. Fig. 10(a) shows a representative SEM image of sample HSZs-24 after 24 h hydrothermal crystallization. Disk-like particles with an almost smooth surface are visible and the sample is highly crystalline as shown by the XRD pattern (Fig. 1(2)). The $\mathrm{N}_{2}$ adsorption-desorption results (Table 1) confirm that the materials have similar textural properties to those of microporous ZSM-5 zeolite. When the hydrothermal treatment was extended to 40 h (HSZs-40), worm-like mesopores appeared on the particle surfaces (Fig. 10(b)) and its XRD intensity decreased slightly (Fig. 1(3)) compared with that of HSZs-24. Similar phenomena were usually observed in post-etching for the preparation of hierarchical zeolites [27]. As listed in Table 1, sample HSZs-40 has a higher specific surface area and larger pore volume than sample HSZs-24 and microporous ZSM-5, which proves that the development of mesoporous structures in the pre-formed zeolite particles occurs through an in-situ etching process. For sample HSZs-120 (Fig. 10(c)), these characteristics became

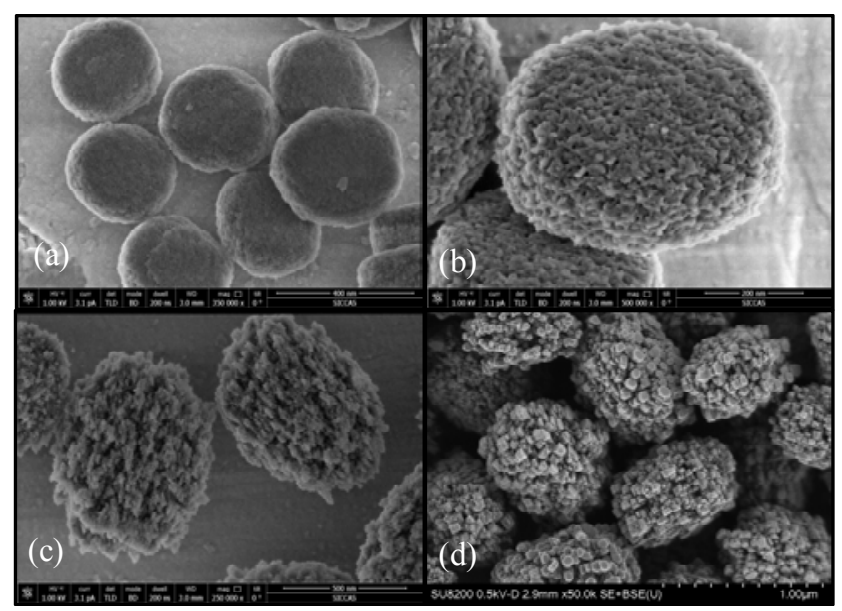

Fig. 10. SEM images of calcined HSZs-24 (a), HSZs-40 (b), HSZs-120 (c), and HSZs-240 (d). more visible as mentioned previously. When the hydrothermal treatment was prolonged to $240 \mathrm{~h}$ (HSZs-240), the in-situ etching process was replaced by secondary crystal growth and many small zeolite grains grew on the pre-formed mesoporous structure of the preceding HSZs particles (Fig. 10(d)). Consequently, the resultant samples became slightly more crystalline (Fig. 1(5)), whereas the mesoporous structures decreased gradually, as shown in Table 1.

In the post-desilication preparation of hierarchical zeolites, Pérez-Ramírez's group $[30,32]$ reported that $\mathrm{TPA}^{+}$cations or aluminum complexes could act as mesopore growth moderators. The development of intracrystalline mesostructure depends on the balance between the affinity of structure-directing agent $\left(\mathrm{TPA}^{+}\right.$or aluminum complexes, which have a strong affinity to the zeolite surface and hinder the attack of $\mathrm{OH}^{-}$) to zeolite surface and dissolution of the crystal framework. Based on the characterization results, a "nucleation/growth-demetallation/recrystallization" mechanism is proposed here as illustrated in Scheme 1. During the initial hydrothermal synthesis stage, zeolite nucleation and growth are predominant and result from the highly concentrated precursor species and relevant concentration fluctuation [33], whereas the basic etching effect is insignificant because of protection by aluminum complexes and $\mathrm{TPA}^{+}$cations that are incorporated in the micropores and dispersed in the reaction system. During the following hydrothermal treatment, basic etching becomes more dominant during the consumption of aluminum complexes and $\mathrm{TPA}^{+}$cations, and consequently mesostructure emerge gradually in pre-formed zeolite particles and HSZs form. Zeolite nucleation/growth and demetallation by basic etching therefore takes place sequentially in a one-pot synthesis, and leads to the formation of HSZs particles. In the later stages of hydrothermal treatment, since the basic etching rate is approximately proportional to the surface area of the dissolving particles and the degree of undersaturation of the reaction solution [34], the pore volume and external surface area will increase rapidly during the creation of mesostructure on the particle surface, and is accompanied by the dissolution of abundant aluminosilicate species in the synthesis solution. Therefore, substantial

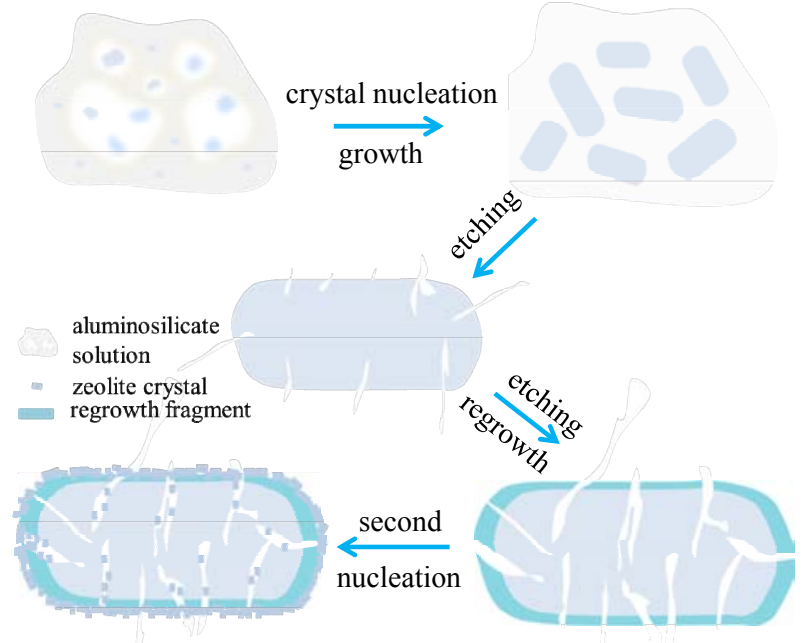

Scheme 1. The mechanism for the formation of HSZs. 
secondary nucleation and/or re-assembly (or re-deposition) and regrowth occurs, and newly formed small zeolite particles will recrystallize and grow on the external surface of pre-formed HSZs [35].

\section{Conclusions}

An easy one-pot hydrothermal method has been reported for the synthesis of hierarchically structured ZSM-5 with a single TPAOH template at a low hydrothermal temperature of 100 ${ }^{\circ} \mathrm{C}$. The resultant HSZs show a high hydrothermal stability and maintain $88 \%$ of the specific surface area of the original samples even after hydrothermal treatment for $48 \mathrm{~h}$ at $150{ }^{\circ} \mathrm{C}$. In a model reaction of TIPB catalytic cracking, the TIPB conversion over as-synthesized HSZs-120 showed a limited reduction from $80 \%$ to $65 \%$ in a $10 \mathrm{~h}$ test, whereas that of the purely microporous counterpart decreased from $55 \%$ to $10 \%$. Based on various structural characterizations, a "nucleation/growthdemetallation/recrystallization" mechanism is proposed for the one-pot HSZs synthesis. This one-pot strategy that combines the hydrothermal crystallization of zeolite particles and basic etching can be regarded as the development of the conventional constructive dual-templating approaches and the destructive post-synthetic methods for HSZs synthesis. This approach of HSZs synthesis is easy and of low cost compared with traditional dual-templating or post-demetallation methods, which is beneficial to the large-scale application of newly developed HSZs materials.

\section{References}

[1] Corma A. J Catal, 2003, 216: 298

[2] Primo A, Garcia H. Chem Soc Rev, 2014, 43: 7548

[3] Urata K, Furukawa S, Komatsu T. Appl Catal A, 2014, 475: 335

[4] Schmidt F, Hoffmann C, Giordanino F, Bordiga S, Simon P, Carrillo-Cabrera W, Kaskel S. J Catal, 2013, 307: 238

[5] Mei C S, Wen P Y, Liu Z C, Liu H X, Wang Y D, Yang W M, Xie Z K, Hua W M, Gao Z. J Catal, 2008, 258: 243

[6] Kim J, Choi M, Ryoo R.J Catal, 2010, 269: 219
[7] Hu Y Y, Liu C, Zhang Y H, Ren N, Tang Y. Microporous Mesoporous Mater, 2009, 119: 306

[8] Kim J C, Cho K, Ryoo R. Appl Catal A, 2014, 470: 420

[9] Choi M, Cho H S, Srivastava R, Venkatesan C, Choi D H, Ryoo R. Nat Mater, 2006, 5: 718

[10] Perez-Ramirez J, Christensen C H, Egeblad K, Christensen C H, Groen J C. Chem Soc Rev, 2008, 37: 2530

[11] Choi M, Na K, Kim J, Sakamoto Y, Terasaki O, Ryoo R. Nature, 2009, 461: 246

[12] Moliner M, Rey F, Corma A. Angew Chem Int Ed, 2013, 52: 13880

[13] Möller K, Bein T. Chem Soc Rev, 2013, 42: 3689

[14] Meng X J, Xiao F S. Chem Rev, 2014, 114: 1521

[15] Ji Y J, Xu H, Wang D R, Xu L, Ji P, Wu H H, Wu P. ACS Catal, 2013, 3: 1892

[16] Jin H L, Ansari M B, Jeong E Y, Park S E. J Catal, 2012, 291: 55

[17] Hamdy M S, Mul G. ChemCatChem, 2013, 5: 3156

[18] Tang B, Dai W L, Sun X M, Guan N J, Li L D, Hunger M. Green Chem, 2014, 16: 2281

[19] White R J, Fischer A, Goebel C, Thomas A. J Am Chem Soc, 2014, 136: 2715

[20] Emdadi L, Wu Y Q, Zhu G H, Chang C C, Fan W, Pham T, Lobo R F, Liu D X. Chem Mater, 2014, 26: 1345

[21] Emdadi L, Liu D X.J Mater Chem A, 2014, 2: 13388

[22] Na K, Jo C, Kim J, Cho K, Jung J, Seo Y, Messinger R J, Chmelka B F, Ryoo R. Science, 2011, 333: 328

[23] Zhou J, Hua Z L, Shi J L, He Q J, Guo L M, Ruan M L. Chem Eur J, 2009, 15: 12949

[24] Zhou J, Hua Z L, Liu Z C, Wu W, Zhu Y, Shi J L. ACS Catal, 2011, 1: 287

[25] Zhu Y, Hua Z L, Zhou J, Wang L J, Zhao J J, Gong Y, Wu W, Ruan M L, Shi J L. Chem Eur J, 2011, 17: 14618

[26] Liu J Y, Wang J G, Li N, Zhao H, Zhou H J, Sun P C, Chen T H. Langmuir, 2012, 28: 8600

[27] Pérez-Ramírez J, Abelló S, Bonilla A, Groen J C. Adv Funct Mater, 2009, 19: 164

[28] Pérez-Ramírez J, Verboekend D, Bonilla A, Abello S. Adv Funct Mater, 2009, 19: 3972

[29] Milina M, Mitchell S, Michels N L, Kenvin J, Pérez-Ramírez J. J Catal, 2013, 308: 398

[30] Abelló S, Bonilla A, Pérez-Ramírez J. Appl Catal A, 2009, 364: 191

[31] Garcia-Martinez J, Li K H, Krishnaiah G. Chem Commun, 2012, 48: 11841

\section{Graphical Abstract}

Chin. J. Catal., 2015, 36: 866-873 doi: 10.1016/S1872-2067(14)60263-1

\section{One-pot synthesis of hierarchically structured ZSM-5 zeolites using single} micropore-template

Tongguang Ge, Zile Hua*, Xiaoyun He, Yan Zhu, Wenchao Ren, Lisong Chen, Lingxia Zhang, Hangrong Chen, Chucheng Lin, Heliang Yao, Jianlin Shi* Shanghai Institute of Ceramics, Chinese Academy of Sciences

An easy one-step low temperature $\left(100{ }^{\circ} \mathrm{C}\right)$ hydrothermal process has been developed for the synthesis of hierarchically structured ZSM-5 zeolites with a single micropore template, and a "nucleation/growth-demetallation/recrystallization" mechanism is discussed.

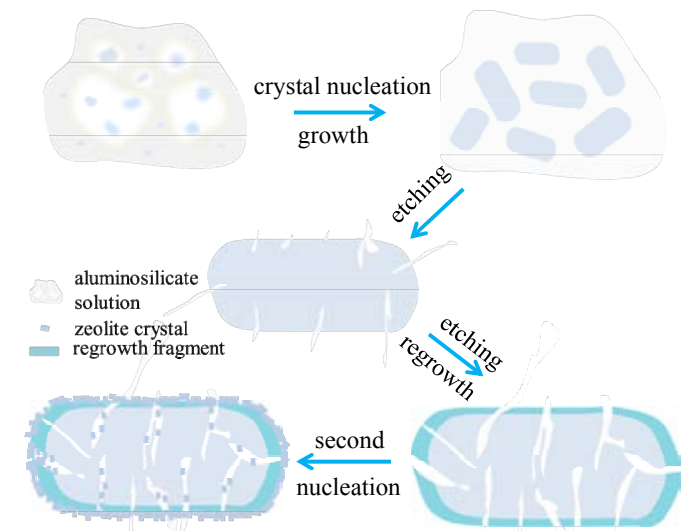


[32] Verboekend D, Perez-Ramirez J. Chem Eur J, 2011, 17: 1137

[33] Li B, Sun B, Qian X F, Li W, Wu Z X, Sun Z K, Qiao M H, Duke M, Zhao D Y.J Am Chem Soc, 2013, 135: 1181
[34] Cundy C S, Cox P A. Microporous Mesoporous Mater, 2005, 82: 1

[35] Yoo W C, Zhang X Y, Tsapatsis M, Stein A. Microporous Mesoporous Mater, 2012, 149: 147

\section{单一微孔模板剂一锅法制备多级结构ZSM-5沸石}

葛同广, 华子乐*, 贺晓耘, 朱 颜, 任文超, 陈立松, 张玲霞, 陈航榕, 林初城, 姚鹤良, 施剑林 ${ }^{\#}$ 中国科学院上海硅酸盐研究所高性能陶瓷和超微结构国家重点实验室, 上海200050

摘要: 以微孔模板剂四丙基氢氧化铵为单一模板剂, 采用一种温和的低温水热一锅法工艺, 成功制备出多级结构ZSM-5沸石 (HSZs). 与传统的双模板法和后处理法相比, 这种结合了沸石生长与后刻蚀于一体的新方法, 不仅减少了模板剂的用量及二次酸/ 碱刻蚀、煅烧造成的环境污染, 同时也极大地简化了合成工艺. 利用XRD, $\mathrm{N}_{2}$ 吸附, SEM, TEM, XRF, ${ }^{27} \mathrm{Al} \mathrm{NMR}$ 与 $\mathrm{NH}_{3}-\mathrm{TPD}$ 等测试 手段对合成的HSZs进行了全面表征, 并提出了一种“成核/生长-刻蚀/再晶化”的形成机理. 与传统ZSM-5沸石相比, 这种具有均一 梭型形貌的HSZs 具有高的水热稳定性, 并在三异丙苯催化裂解的探针反应中表现出优异催化性能和较长使用寿命.

关键词: 多级结构沸石; ZSM-5; 单一模板; 碱刻蚀; 催化

收稿日期: 2014-10-30. 接受日期: 2014-12-10. 出版日期: 2015-06-20.

“通讯联系人.电话: (021)52412708; 传真: (021)52413122; 电子信箱: huazl@mail.sic.ac.cn

\#通讯联系人。电话: (021)52412712; 传真: (021)52413122; 电子信箱: jlshi@mail.sic.ac.cn

基金来源：国家重点基础研究发展计划(973计划, 2013CB933200); 国家高技术研究发展计划(863计划, 2012AA062703); 国家杰 出青年科学基金(51225202); 重质油国家重点实验室开放课题(SKLOP201402003).

本文的英文电子版由Elsevier出版社在ScienceDirect上出版(http://www.sciencedirect.com/science/journal/18722067). 